\title{
Anti-Helicobacter pylori Activity and Structure-Activity Relationships of Berberine Derivatives
}

\author{
Yeong-Hwan Han, Kap-Duk Lee, and Dong-Ung Lee* \\ Division of Bioscience, Dongguk Chiversity; Gueongiu 780-714. Korea. E-mail: duleeiâdonggukack \\ - Department of Nanomaterial Chemistry. Dongguk University, Gieongin 780-714, Korea \\ Received October 22, 2009, Accepted November 23, 2009
}

Key Words: Helicobacter pylori. Berberine analogs. Urease. Structure-activity relationship

In 1983, Warren and Marshall found that gastritis and most stomach ulcers are caused by Helicobacter pulori infection. and not by stress or spicy food. as had been previously assumed. ${ }^{j}$ This bacteria is known to produce a toxin that may be potentiated by ammonia generated from urease. ${ }^{2}$ Since that time. many types of anti- $H$. pvori agents focusing on inhibition of $H$. prori growth and/or anti-urease activity have been chemically synthesized $^{3}$ or isolated from natural sources ${ }^{4}$ for treatment of patients with gastroduodenal disorders. For example. administration of a mixture of such synthetic compounds as bismuth subsalicylate. tetracycline, and metronidazole for eight weeks was found to inhibit growth of $H$. pvori " but with adverse side-effects due to long treatment periods. Natural products, such as decurcin. decurcinol angelate berberine, and magnolol have been reported to demonstrate moderate inhibition of $H$. prlori growth ${ }^{4}$

Among the natural compounds tested for anti-H. pvlori activity to date. we focused on berberine. owing to its extensive anti-bacterial activity including anti- $H$. pvlori activity. Berberine is a major constituent of Coptis chinensis and Phellodendron amurense. which are used in the Orient for treatment of diarrhea and other gastrointestinal diseases. Although berberine was known to inhibit the growth of $H . p_{y} / o r i,{ }^{6}$ its derivatives have not thoroughly been investigated yet. We have previously' discussed the antimicrobial. antimalarial. ${ }^{8}$ and anticancer activities $^{3}$ of the synthetic protoberberine-type alkaloids. In the present study. we prepared berberine derivatives in order to evaluate their inhibitory activity against $H$. pryori and urease, which play important roles in pathogenesis of gastric ulcers. Nine synthetic protoberberine alkaloids (four 8-alkyl-dihydroberberines two 8-alkyl-berberines. and three 12-bromo-8-alky'lberberines) (Scheme 1). including three unreported analogs. and natural berberine and palmatine were tested for elucidation of both their activity and their structure-activity relationships.
The effect of growth inlubition by berberine (1) against $H$. pvlori was much stronger than that of palmatine (2) (Fig. 1). proving that activity of the methylenedioxy group is more significant than that of the methoxy group. Dihydroberberines (5 or 6) showed weaker activity than the corresponding berberines (7 or 8), suggesting that ring $\mathrm{C}$ should be aromatic. Inhibitory activity was increased in proportion to the number of carbons at the $\mathrm{C}-8$ position, suggesting that greater lipophilicity is an indication of stronger activity (e.g. $3<4<5$ ): however. the longer hexyl side chain resulted in decreased activity ( 6 or 8 ). Among nime berberine analogs tested. five compounds showed stronger activity than berberine itself. Introduction of an $n$-butyl group at the C-8 position of berberine resulted in significantly increased activity in comparison with other alkyl groups (com-

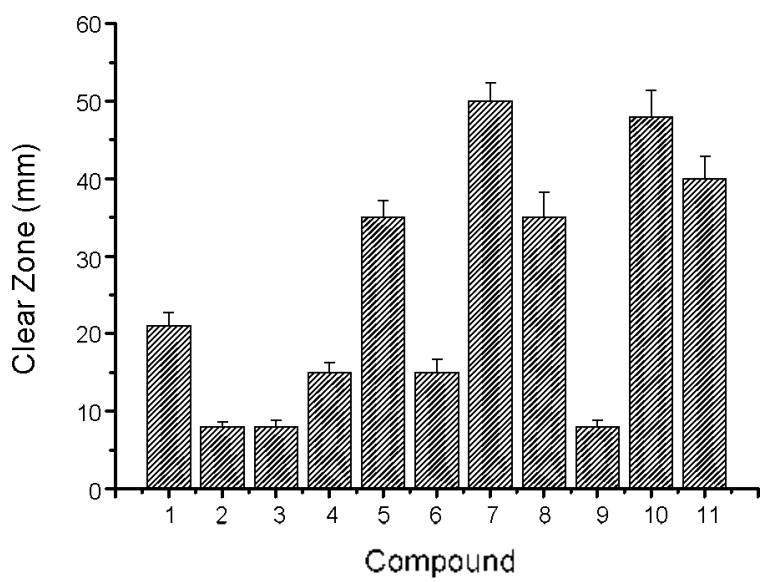

Figure 1. Inhibitory effect of berberine (1), palmatine (2) and synthetic analogs against Helicolacter pvion at a final concentration of $1.25 \mathrm{mg} / \mathrm{mL}$. Data represent the mean $\pm \mathrm{S}$. D. $(n=3)$.

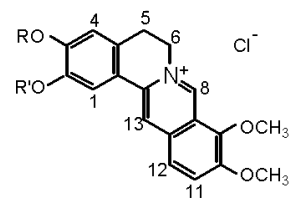

1: $\mathrm{R}+\mathrm{R}^{\prime}=\mathrm{CH}_{2}$ 2: $\mathrm{R}=\mathrm{R}^{\prime}=\mathrm{CH}_{3}$
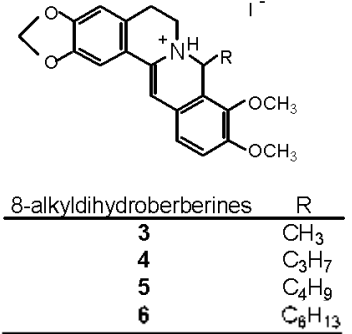
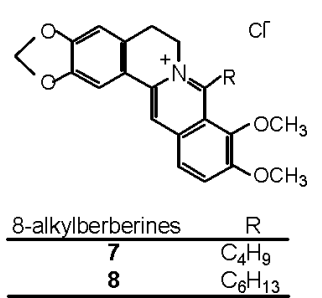
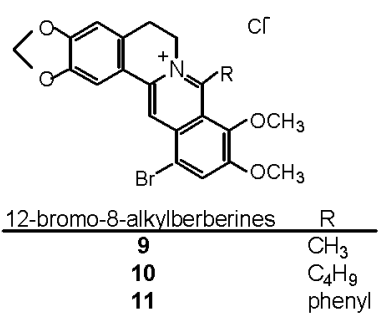

Scheme 1. Chemical structures of natural protoberberines (1 and 2) and synthetic compounds tested 


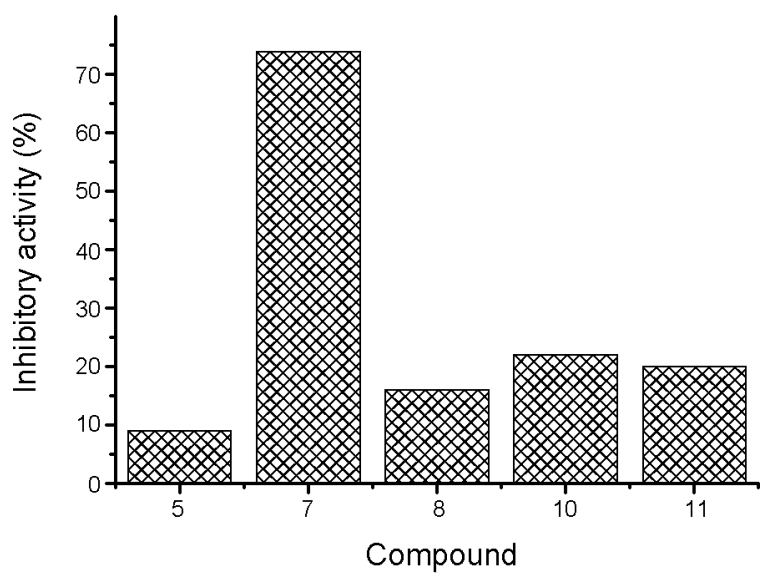

Figure 2. Urease inhibitory effect of some synthetic compounds having stronger anti-Helicobacfer pulori activity than that of berberine (1) at a final concentration of $1.0 \mathrm{mg} / 1 \mathrm{~nL}, n=2$.

pare 5 with $3,4,6$. or 7 with 8 . or 10 with 9,11 ). Replacement of $\mathrm{H}-12$ of 7 by a bromine atom did not affect activity much. As a result. 8-butyl-substituted berberine derivatives ( 7 and 10) exhibited the most effective anti-H. pvlori activity.

Our previous reports indicated that the antibacterial and antifungal activities of C-8-substituents increased as the aliphatic chain lengthened. supporting the above results. However. although an antibacterial activity of 7 was much weaker than that of 10 anti-H. pvori activity of both compounds were nearly the same.

Next. compounds 5, 7, 8, 10. 11, which suppress growth of H. pylori more than berberine. were investigated for their inhibitory activity against urease. Urease is considered to play a key role in growth of $H$. pyori because the bacteria can survive in the strongly acidic conditions of the stomach through neutralization of acid with ammonia forming from turease. Among the tested compounds, 8-butylberberine (7) revealed potent antiurease activity, with $73.9 \%$ inhibition. at a concentration of $1.0 \mathrm{mg} / \mathrm{mL}$. and the others showed relatively weak activity (Fig. 2). DMSO used as a solvent showed no antibacterial and urease inhibitory activity.

In conclusion, 8-butylberberine ( 7 ) would be acceptable as a superior anti- $H$. pvori agent based on its suppressing effect on bacterial growth as well as its inhibitory property on urease activity.

\section{Experimental Section}

General. Melting point was measured on an Electrothermal IA9100 apparatus (Thermo Scientific. Pittsburgh, PA. USA), and was uncorrected. NMR spectra were recorded on a Varian VXR-500 $(500 \mathrm{MHz})$. Liquid secondary ion mass spectra (LSIMS. positive ion) were determined on a Hitachi M-4100 instrument, using glycerol as a matrix. Berberine and palmatine were obtained from Sigma-Aldrich (St. Louis. MO. USA). All other compounds tested. with the exception of compounds 6 . 8. and 9. were previously prepared. ${ }^{6.8}$

Preparation of 8-hexyldihydroberberine iodide (6): According to procedures for compounds 3-5. 8-hexyl derivative was prepared using Grignard reagent (mixture of $\mathrm{Mg}$ turning and n-hexyl iodide in anhy'drous ether). Recrystallization with $80 \%$ $\mathrm{MeOH}$ yielded a dark brown powder. Yield $45 \%$. mp. $146-$ $157^{\circ} \mathrm{C} .{ }^{1} \mathrm{H}-\mathrm{NMR}\left(\mathrm{DMSO}-d_{6}\right) \delta 0.95\left(\mathrm{CH}_{3} . \mathrm{t}, J=7.0 \mathrm{~Hz}, 3 \mathrm{H}\right)$, $1.35-1.80$ and $3.43\left(5 \times \mathrm{CH}_{2}, \mathrm{~m}\right) .3 .17(\mathrm{H}-5, \mathrm{t} . J=6.0 \mathrm{~Hz}), 4.08$ (9-OMe. s). 4.13 (10-OMe, s). $4.80(\mathrm{H}-6 . \mathrm{t} . J=6.0 \mathrm{~Hz}) .5 .32$ $(\mathrm{H}-8 . \mathrm{s}), 6.20\left(\mathrm{OCH}_{2} \mathrm{O} . \mathrm{s}\right) .7 .11$ (H-4. s). 7.52 (H-1, s). 7.80 $(\mathrm{H}-12 . \mathrm{d}, J=9.0 \mathrm{~Hz}) .8 .03(\mathrm{H}-11, \mathrm{~d}, J=9.0 \mathrm{~Hz}) .8 .52(\mathrm{H}-13, \mathrm{~s})$. PI-LSIMS $m / z:+22$ [M-I] $H^{+}$(nww. 549 for $\mathrm{C}_{23} \mathrm{H}_{3} \mathrm{NO}_{4} \mathrm{I}$ ).

Preparation of 8-hexylberberine chlonide (8): Hỳdroiodide 6 was delydrogenated. then converted into the corresponding chloride in the same manner as that of other alkyl substituents. fumishing 8 as a yellow powder. Yield $52 \%$ ntp. $185-191{ }^{\circ} \mathrm{C}$. ${ }^{\mathrm{J}} \mathrm{H}-\mathrm{NMR}$ (DMSO- $\left.d_{6}\right) \mathrm{\delta} 0.92\left(\mathrm{CH}_{3}, \mathrm{t}, J=7.0 \mathrm{~Hz}, 3 \mathrm{H}\right), 1.38-1.82$ and $3.49\left(5 \times \mathrm{CH}_{2}, \mathrm{~m}\right), 3.18(\mathrm{H}-5, \mathrm{t} . J=6.0 \mathrm{~Hz}) .4 .05(9-\mathrm{OMe}, \mathrm{s})$. $4.11(10-\mathrm{OMe}, \mathrm{s}), 4.81(\mathrm{H}-6 . \mathrm{t} . J=6.0 \mathrm{~Hz}), 6.18\left(\mathrm{OCH}_{2} \mathrm{O}, \mathrm{s}\right) .7 .14$ $(\mathrm{H}-4 . \mathrm{s}) .7 .56(\mathrm{H}-\mathrm{l}, \mathrm{s}) .7 .78(\mathrm{H}-12, \mathrm{~d} . J=9.0 \mathrm{~Hz}) .8 .09(\mathrm{H}-\mathrm{ll}$. d. $J=9.0 \mathrm{~Hz}$ ). $8.54(\mathrm{H}-13, \mathrm{~s})$. PI-LSIMS $m / z+20[\mathrm{M}-\mathrm{Cl}]^{+}(\mathrm{nmw}$. 455 for $\mathrm{C}_{26} \mathrm{H}_{310} \mathrm{NO}_{4} \mathrm{Cl}$ ).

Preparation of 12-bromo-8-methylberberine chloride (9): 9 was prepared according to the method applied to synthesis of related compounds. yielding a brown powder. Yield 35\%. mp. $204-211{ }^{\circ} \mathrm{C}$. ${ }^{\mathrm{H}} \mathrm{H}-\mathrm{NMR}$ (DMSO- $\left.d_{6}\right)$ ô $3.41\left(\mathrm{CH}_{3} . \mathrm{s}, 3 \mathrm{H}\right) .3 .27$ $(\mathrm{H}-5, \mathrm{t} . J=6.0 \mathrm{~Hz}),+.12$ (9-OMe. s) 4.22 (10-OMe, s). 4.95 $(\mathrm{H}-6, \mathrm{t}, J=6.0 \mathrm{~Hz}) \cdot 6.13\left(\mathrm{OCH}_{2} \mathrm{O} . \mathrm{s}\right) .6 .98(\mathrm{H}-4, \mathrm{~s}), 7.68(\mathrm{H}-1$. s). $8.43(\mathrm{H}-11, \mathrm{~s}) .8 .6 \mathrm{l}(\mathrm{H}-13$. s). PI-LSIMS $m / 2+28$ and 430 $[\mathrm{M}-\mathrm{Cl}]^{+}$(mw. 464 for $\mathrm{C}_{21} \mathrm{H}_{19} \mathrm{NO}_{4} \mathrm{BrCl}$ ).

Bacteria and growth conditions. H. pvori (KCCM 41351) was obtained from the Korean Culture Center of Microorganisms. The bacterium was grown on brucella agar containing $10 \%$ fetal bovine senum (FBS) under microaerophilic conditions $\left(5 \% \mathrm{O}_{2}, 10 \% \mathrm{CO}_{2}, 10 \% \mathrm{H}_{2}\right.$. and $\left.75 \% \mathrm{~N}_{2}\right)$ in anaerobic jars with gas mixture systems at $37^{\circ} \mathrm{C}$ for $3 \sim 5$ days

Bacterial growth inhibition assay. Growth inhibition was performed using the Kirby-Bauer method on brucella agar containing $10 \%$ FBS under microaerophilic conditions at $37{ }^{\circ} \mathrm{C}$ : $100 \mu \mathrm{L}$ of this cell suspension was smeared over the entire surface of a brucella agar plate containing $10 \%$ FBS. Berberine derivatives (final concentration $1.25 \mathrm{mg} / \mathrm{mL}$ ) were dropped onto paper discs. and the latter were placed on agar plates. Diameter of inhibition zones were measured after 3 days of incubation at $37^{\circ} \mathrm{C}$ under microaerophilic conditions

Preparation of uease. Broth cultured cells were harvested by centrifugation $(15,000 \times \mathrm{g} .10 \mathrm{~min})$. Harvested $H$. pvlori cells were washed with $5 \mu \mathrm{L}$ of $20 \mathrm{mM}$ citrate buffer ( $\mathrm{pH} 5.0$ ), then resuspended in the same buffers. Cells were disnupted using a French press (Fred S. Carver Inc.. 15.000 psi), centrifuged at $15,000 \times \mathrm{g}$ for $10 \mathrm{~min}$, and supematants were used for the urease activity assay

Ulease activity assay. Urease activity was assayed according to the known method. ${ }^{\text {I1 }}$ Reaction mixtures comprising $100 \mu \mathrm{L}$ of enzyme solution, $300 \mu \mathrm{L}$ of buffer containing 400 nM urea, and $50 \mu \mathrm{L}$ of berberine derivatives (final concentration 1.0 $\mathrm{mg} / \mathrm{mL}$ ) were incubated at $37^{\circ} \mathrm{C}$ for $30 \mathrm{~min}$. after which 100 $\mu \mathrm{L} 1 \mathrm{~N} \mathrm{H}_{2} \mathrm{SO}_{4}$ was added. For ammonia determination using the indophenol method. $2.5 \mathrm{~mL}$ each of phenol reagent $(1 \% \mathrm{w} / \mathrm{v}$ phenol and $0.005 \% \mathrm{w} / \mathrm{v}$ sodium nitroprusside) and an alkali reagent $\left(5.5 \% \mathrm{w} / \mathrm{Na} \mathrm{Na}_{2} \mathrm{HPO}_{4} \cdot 12 \mathrm{H}_{2} \mathrm{O} .0 .5 \% \mathrm{w} / \mathrm{NaOH}\right.$, and $0.1 \%$ 
active chloride $\mathrm{NaOCl}$ ) were added to each reaction mixture. Following incubation at $65^{\circ} \mathrm{C}$ for $20 \mathrm{~min}$, absorbance was measured at $630 \mathrm{~nm}$. Inhibition ratio was calculated as a percentage of that in the control experiment, in which $50 \mu \mathrm{L}$ of DMSO was added instead of the test compound solution.

\section{References}

1. Marshall, B. T.; Warren, J. R. Lancet. 1984, 323, 1311 .

2. Ysujii, M.; Kawano, N.: Tsukii, S.: Fusannoto, H.: Kannada, T.: Sato, N. Gastroenterol. 1992,102, 1881

3. Cheng, N.: Xie, T. S : Zhang, M. Y.; Shu, C.: Zhu, D. X. Bioorg. Aed Chem. Lett. 2003, 13, 2703

4. Mahady, G. B.: Pendland, S. L.: Stoia, A.: Chadwick, L. R. Phvtother. Res. 2003, 17,217.
5. Hentschel, E.; Brandstatter, G.: Dragsics, B.; Hirschil, A. M.; Nemec, H.: Schutze, K.; Taufer, M.; Wurzer, H. N. Engl. J. hed. 1993, 328, 308.

6. Bae, E. A.; Han, M. J.; Kim, N. J.; Kim, D. H. Biol Pham. Bull. $1998,21,990$.

7. Iwasa, K.; Lee, D. U.: Kang, S. I.: Wiegrebe, W. J. Kat. Prod. 1998 , 61,1150 .

8. Iwasa, K.; Kim, H. S.; Wataya, Y,; Lee, D. U. Eur. J. Med Chent. $1998,33,65$.

9. Iwasa, K:; Moriyasu, M.: Yamori, T.: Turno, T.: Lee, D. U.; Wiegrebe, W. J. Nat. Prod. 2001, 64,896.

10. Celli, I. P.; Tumer, B. S.; Afdhal, N. H.; Keates, S.; Ghiran, I.; Kelly, C. P.; Ewoldt, R. H.; McKinley, G. H.; So, P.; Erramilli, S. Proc Natl Acad Sci. li S . A. 2009, 106, 14321.

11. Pervez, H.: Iqbal, M. S.: Tahir, M. Y.; Nasim. F. U. H.: Choudhary, M. I.: Khan, K. M. J. Enzm. Inhb. Aled. Chem 2008, 23, 848. 